\title{
ADMINISTRACYJNE ZARZĄDZENIE ZABEZPIECZENIA JAKO PODSTAWA WPISU HIPOTEKI PRZYMUSOWEJ
}

I. Zarządzenie zabezpieczenia określone w przepisach ustawy o postępowaniu egzekucyjnym $\mathrm{w}$ administracji ${ }^{1}$ jest jedna $\mathrm{z}$ form uzyskania wpisu hipoteki przymusowej, o którym mowa w art. 110 u.k.w.h. ${ }^{2}$ Uprawnienie ustanowienia hipoteki przymusowej przysługuje wierzycielowi, w tym także organom podatkowym, a instytucja ta pozwala na zabezpieczenie zobowiązań podatkowych także przed terminem płatności. Zastosowanie hipoteki przymusowej w prawie podatkowym wymaga odniesienia do regulacji prawa cywilnego.

Celem artykułu jest analiza zagadnień związanych z zabezpieczeniem zobowiązań podatkowych przed wydaniem decyzji ustalającej lub określającej wysokość zobowiązania podatkowego. Omówiono zagadnienia dotyczące wygaśnięcia oraz uchylenia decyzji o zabezpieczeniu. Podjęto próbę odpowiedzi na pytanie, czy uchylenie decyzji o zabezpieczeniu może mieć wpływ na upadek skutków zarządzenia zabezpieczenia, jako merytorycznej podstawy wpisu hipoteki przymusowej. Ponadto zbadano okoliczności mające wpływ na uchylenie zarządzenia zabezpieczenia jako aktu administracyjnego stanowiącego podstawę wpisu hipoteki przymusowej. Przesłanki te rozpatrywano w kontekście nowych faktów i dowodów w apelacyjnym postępowaniu wieczystoksięgowym.

II. W przepisach ustawy o postępowaniu egzekucyjnym w administracji zostały przewidziane trzy formy zabezpieczania należności pieniężnych. Pierwsza dotyczy zabezpieczenia wymagalnej lub przeterminowanej należności pieniężnej (art. $154 \S 1$ u.p.e.a.). Druga forma odnosi się do zabezpieczenia należności pieniężnej niewymagalnej, tj. przed terminem płatności należności pieniężnej lub przed terminem wykonania obowiąku o charakterze niepieniężnym (art. $154 \S 2$ u.p.e.a.). Trzecia forma wskazuje na możliwość zabezpieczenia przed ustaleniem albo określeniem kwoty należności pieniężnej lub obowiązku o charakterze niepieniężnym, jeżeli brak zabezpieczenia mógłby utrudnić lub udaremnić skuteczne przeprowadzenie egzekucji, a przepisy odrębne zezwalają na takie zabezpieczenie (art. 155 u.p.e.a). Do przepisów odrębnych zaliczyć można regulację zawartą w art. 33 o.p. ${ }^{3}$, w którym wyodrębniono możliwość zabezpieczenia należności podatkowej przed terminem

${ }^{1}$ Ustawa z 17 czerwca 1966 r. o postępowaniu egzekucyjnym w administracji, t.jedn.: Dz. U. 2017, poz. 1201 (dalej jako: u.p.e.a.).

${ }^{2}$ Ustawa z 6 lipca 1982 r. o księgach wieczystych i hipotece, t.jedn.: Dz. U. 2017, poz. 1007 (dalej jako: u.k.w.h.).

${ }^{3}$ Ordynacja podatkowa z 29 sierpnia 1997 r., t.jedn.: Dz. U. 2017, poz. 201 (dalej jako: o.p.). 
płatności lub przed wydaniem decyzji ustalającej bądź określającej wysokość zobowiązania podatkowego.

Zabezpieczenie zobowiazania podatkowego wykazuje odrębne cechy w stosunku do zabezpieczenia określonego w przepisach o postępowaniu egzekucyjnym w administracji. Przepisy Ordynacji podatkowej stanowia lex specialis w stosunku do przepisów działu IV „Postępowanie zabezpieczające” ustawy o postępowaniu egzekucyjnym $\mathrm{w}$ administracji ${ }^{4}$. Przepisy te umożliwiaja zabezpieczenie zobowiązania podatkowego przed terminem płatności na majątku podatnika, a w przypadku osób pozostających w związku małżeńskim także na majątku wspólnym, jeżeli zachodzi uzasadniona obawa, że nie zostanie ono wykonane. Dotyczy to w szczególności sytuacji, w której podatnik trwale nie uiszcza wymagalnych zobowiązań o charakterze publicznoprawnym lub dokonuje czynności polegających na zbywaniu majątku, które mogą utrudnić lub udaremnić egzekucję. W przypadku wystapienia wskazanych okoliczności zabezpieczenia można dokonać również przed wydaniem decyzji ustalającej lub określającej wysokość zobowiązania podatkowego bądź określającej wysokość zwrotu podatku. Organ podatkowy wydaje wówczas decyzję o zabezpieczeniu, w której określa przybliżoną wysokość podstawy opodatkowania, przybliżoną kwotę zobowiązania podatkowego lub przybliżoną kwotę zobowiązania podatkowego oraz kwotę odsetek za zwłokę należnych od tego zobowiązania na dzień wydania decyzji o zabezpieczeniu (art. $33 \S 4$ o.p.). Decyzja o zabezpieczeniu stanowi podstawę wystawienia zarządzenia zabezpieczenia, o którym mowa w przepisach u.p.e.a.

Zarządzenie zabezpieczenia jest dokumentem urzędowym wystawionym przez wierzyciela, uprawniającym do wszczęcia i prowadzenia postępowania zabezpieczającego, który stanowi podstawę dokonania zabezpieczenia należności pieniężnych przez zastosowanie środków zabezpieczenia. W orzecznictwie podkreśla się, że zarządzenie zabezpieczenia jest aktem administracyjnym niebędącym decyzją administracyjna, dlatego też nie odnoszą się do niego wymagania formalne określone dla decyzji, przewidziane w art. 107 k.p.a. ${ }^{5}$ Wymogi, jakie powinno spełniać zarządzenie zabezpieczenia, zostały określone w przepisach u.p.e.a. Jeden z podstawowych wymogów dotyczy formy sporządzenia zarządzenia zabezpieczenia. Powinno być ono sporządzone na urzędowym formularzu (ZZ-1). Kolejne wymogi, które powinno spełniać zarządzenie zabezpieczenia, zostały określone w art. $156 \S 1$ u.p.e.a. Zarządzenie zabezpieczenia powinno zawierać wszystkie elementy wyszczególnione w tym przepisie. Brak jednego z elementów bądź nieprawidłowe wypełnienie zarządzenia zabezpieczenia może być podstawa zwrotu tego zarządzenia wierzycielowi w formie postanowienia organu egzekucyjnego na podstawie art. 157 $\S 1$ u.p.e.a. ${ }^{6}$ bądź podstawą zarzutu w sprawie prowadzenia postępowania zabezpieczającego określonego w art. 33 pkt $10 \mathrm{w}$ zw. z art. $166 \mathrm{~b}$ u.p.e.a. ${ }^{7}$

\footnotetext{
${ }^{4}$ Zob. wyrok NSA z 13 stycznia 1998 r., III SA 1112/96, Legalis nr 43726.

5 Postanowienie SN z 9 sierpnia 2016 r., II CSK 710/15, Legalis nr 1507563.

${ }^{6}$ Wyrok WSA w Poznaniu z 22 maja 2013 r., I SA/Po 124/13, Legalis nr 780879.

7 Wyrok NSA z 23 września 2011 r., II FSK 629/10, Legalis nr 388063.
} 
Zarządzenie zabezpieczenia nie podlega weryfikacji w trybach zwykłych ani nadzwyczajnych określonych przepisami k.p.a. ${ }^{8}$ Zasadność wystawienia oraz prawidłowość wypełnienia zarządzenia zabezpieczenia podlega ocenie przez organ egzekucyjny na zasadach określonych przepisami u.p.e.a. przed nadaniem klauzuli o przyjęciu zarządzenia do wykonania bądź w trybie zarzutów zgłoszonych przez zobowiązanego ${ }^{9}$.

Pojawiły się wątpliwości związane z prawidłowym wprowadzeniem do obrotu prawnego decyzji o zabezpieczeniu a możliwością wystawienia zarządzenia zabezpieczenia. Wątpliwości dotyczyły kwestii możliwości jednoczesnego doręczenia decyzji o zabezpieczeniu i zarządzenia zabezpieczenia. Zagadnienie to było przedmiotem rozważań sądów administracyjnych, w tym Naczelnego Sądu Administracyjnego ${ }^{10}$. W jednym z kluczowych wyroków NSA sformułował tezę, że wystawienie przez organ podatkowy zarządzenia zabezpieczenia, o którym mowa w art. 155 u.p.e.a. w zw. z art. 33 § 2 , § 4 i $\S 5$ o.p., nie mogło nastapić wcześniej od doręczenia przez ten organ decyzji o zabezpieczeniu. Tożsame stanowisko NSA zają w późniejszym orzeczeniu ${ }^{11}$, konstatując, że z art. $155 \mathrm{a} \S 1 \mathrm{w}$ zw. z art. $156 \S 1$ pkt 3 u.p.e.a. wynika, że zarządzenie zabezpieczenia należności pieniężnej określonej w decyzji o zabezpieczeniu, o której mowa w art. $33 \S 4$ pkt 2 o.p. w zw. z art. 155 u.p.e.a., nie może być wydane przed doręczeniem decyzji o zabezpieczeniu; wyjaśnił, że decyzja o zabezpieczeniu ma charakter konstytutywny, co oznacza, że wywołuje ona skutek w postaci zwiąania organu wydaną decyzja i wprowadzenia jej do obrotu prawnego dopiero z chwila jej doręczenia (art. 212 o.p., zasada związania decyzja podatkową od chwili jej doręczenia).

$\mathrm{Z}$ dniem 1 stycznia $2016 \mathrm{r}$. do porządku prawnego wprowadzono art. $155 \mathrm{~b}$ $\S 1$ 1a u.p.e.a., na mocy którego organ egzekucyjny lub egzekutor może doręczyć zobowiązanemu decyzję o zabezpieczeniu wraz z odpisem zarządzenia zabezpieczenia wtedy, gdy doręczenie odpisu zarządzenia po doręczeniu decyzji o zabezpieczeniu (o której mowa w art. 33 o.p.) mogłoby utrudnić lub udaremnić dokonanie zabezpieczenia. W ten sposób została przyjęta zasada, że wydanie i doręczenie zobowiązanemu decyzji o zabezpieczeniu poprzedza wydanie zarządzenia zabezpieczenia, a możliwość jednoczesnego doręczenia zobowiązanemu decyzji o zabezpieczeniu i odpisu zarządzenia zabezpieczenia stanowi wyjątek od tej zasady, który został obwarowany wystapieniem dodatkowych przesłanek ${ }^{12}$ wskazujących na możliwość utrudnienia lub udaremnienia zabezpieczenia.

III. Decyzja o zabezpieczeniu, jako decyzja ustalająca hipotetyczną kwotę zobowiązania podatkowego, wygasa po upływie 14 dni od dnia doręczenia

${ }^{8}$ M. Faryna, Komentarz do art. 155a, w: D.R. Kijowski (red.) et al., Ustawa o postepowaniu egzekucyjnym $w$ administracji. Komentarz, Lex 2015, nb 5.2.

${ }^{9}$ Ibidem, nb 5.2.

${ }^{10}$ Zob. np. wyroki NSA: z 13 stycznia 1998 r., III SA 1112/96, Legalis nr 43726; z 25 maja 2010 r., II FSK 112/09, Legalis nr 293537; z 15 lutego 2013 r., II FSK 1204/11, Legalis nr 649179.

${ }_{11}$ Wyrok NSA z 15 lutego 2013 r., II FSK 1204/11, Legalis nr II FSK 1204/11.

${ }_{12}$ Postanowienie NSA z 12 kwietnia 2016 r., II FSK 312/14, Legalis nr 1467200. 
decyzji ustalającej wysokość zobowiązania podatkowego lub określającej wysokość zobowiązania podatkowego lub określającej wysokość zwrotu podatku (art. 33a o.p.).

$\mathrm{Na}$ tle tej regulacji powstało wiele wątpliwości zarówno w doktrynie, jak i orzecznictwie ${ }^{13}$. Dotyczyły one przede wszystkim problemu, czy skutkiem wygaśnięcia decyzji o zabezpieczeniu nie powinno być umorzenie postępowania odwoławczego jej dotyczacego. Kwestia ta jest istotna z punktu widzenia podejmowanego tematu, gdyż umorzenie postępowania odwoławczego od decyzji stanowiącej podstawę wystawienia zarządzenia zabezpieczenia skutkuje brakiem podstawy do podważenia bytu prawnego zarządzenia zabezpieczenia jako merytorycznej podstawy zabezpieczania.

W zakresie wzajemnej korelacji pomiędzy wygaśnięciem decyzji o zabezpieczeniu a umorzeniem postępowania odwoławczego dotyczącego tej decyzji ukształtowały się dwa przeciwstawne poglądy. Zgodnie z dominującym pogladem wygaśnięcie decyzji o zabezpieczeniu powoduje bezprzedmiotowość postępowania odwoławczego, co w konsekwencji powinno prowadzić do umorzenia postępowania ${ }^{14}$. Zajmujący odmienne stanowisko wykazywali, że wygaśnięcie decyzji o zabezpieczeniu nie uzasadnia umorzenia postępowania odwoławczego w sprawie zabezpieczenia zobowiązania podatkowego jako bezprzedmiotowego. Przyjęcie bezprzedmiotowości postępowania odwoławczego wskutek wygaśnięcia decyzji o zabezpieczeniu prowadzi nie tylko do pozbawienia strony możliwości pozyskania rozstrzygnięcia merytorycznego przez izby skarbowe zasadności podejmowanych przez urzędy skarbowe decyzji, ale również wyłączenia tych spraw spod kontroli sądowej ${ }^{15}$.

Powstałe wątpliwości zostały rozstrzygnięte uchwała składu siedmiu sędziów NSA ${ }^{16}$, w której wyrażono pogląd, że wygaśnięcie decyzji o zabezpieczeniu (na podstawie art. 33a $\S 1$ pkt 2 i 3 o.p.) powoduje konieczność umorzenia postępowania odwoławczego dotyczącego tej decyzji na podstawie art. $233 \S 1$ pkt 3 o.p., gdyż postępowanie to stało się bezprzedmiotowe. Nie mogą bowiem w obrocie prawnym równolegle istnieć dwie decyzje dotyczace tej samej materii, czyli decyzja o zabezpieczeniu oraz decyzja wymiarowa ${ }^{17}$.

Umorzenie postępowania odwoławczego w sprawie decyzji stanowiacej podstawę wystawiania zarządzenia zabezpieczenia skutkuje utrzymaniem

${ }_{13}$ Zob. np. postanowienie NSA z 20 stycznia 2011 r., I FSK 2053/09, Legalis nr 328480 z glosa: T. Brzezicki, W. Morawski, Postępowanie odwoławcze a wygaśnięcie decyzji o zabezpieczeniu, „Monitor Podatkowy” 2011, nr 6, s. 45.

${ }^{14}$ Zob. wyroki NSA: z 9 marca 2010 r., II FSK 1763/08, Legalis nr 223756; z 26 stycznia 2010 r., II FSK 1451/08, Legalis nr 223356. Problematyka ta była szeroko komentowana przez doktrynę - zob. np. W. Stachurski, Komentarz do art. 33a, w: L. Etel (red.) et al., Ordynacja podatkowa. Komentarz aktualizowany, Lex/el. 2018, nb. 3; S. Babiarz, Komentarz do art. 33a, w: B. Dauter et al., Ordynacja podatkowa. Komentarz, Lex/el. 2018, nb. 4.

${ }_{15}$ Wyrok NSA z 8 listopada 2002 r., III SA 820/01, Legalis nr 57024.

${ }^{16}$ Uchwała NSA z 24 października 2011 r., I FPS 1/11, „Orzecznictwo Naczelnego Sądu Administracyjnego i Wojewódzkich Sądów Administracyjnych” 2012, nr 1, poz. 2, z glosą M. Borkowski, „Przegląd. Podatkowy” 2012, nr 1, s. 43, z glosą T. Nieborak „Orzecznictwo Sądów Polskich” 2012, nr 7-8, poz. 71, s. 481; wyrok NSA z 8 listopada 2016 r., II FSK 1385/13, Legalis nr 1554474.

${ }^{17}$ Wyrok NSA z 14 grudnia 2000 r., III SA 7499/98, Legalis nr 49914. 
w obrocie prawnym dokumentu zabezpieczenia, ponieważ prima facie wydaje się, że nie ma merytorycznej podstawy do jego podważenia. Podobna sytuacja występuje w przypadku wygaśnięcia decyzji o zabezpieczeniu, w której także nie dochodzi do naruszenia zarządzenia zabezpieczenia wydanego na podstawie przepisów o postępowaniu egzekucyjnym w administracji (art. 33a $\S 2$ o.p.). Oznacza to, że wygaśnięcie decyzji o zabezpieczeniu nie powoduje „automatycznego” wygaśnięcia zarządzenia zabezpieczenia.

Od wygaśnięcia decyzji o zabezpieczeniu należy odróżnić uchylenie decyzji o zabezpieczeniu. Do uchylenia decyzji o zabezpieczeniu może dojść w toku kontroli instancyjnej. Podstawą uchylenia decyzji w postępowaniu administracyjnym może być interes społeczny lub słuszny interes strony (art. 154 $\S 1$ k.p.a. ${ }^{18}$ lub art. 155 k.p.a.). Wówczas organ administracji publicznej, który wydał decyzję, może ją uchylić, jeżeli przepisy szczególne się temu nie sprzeciwiajac. Do uchylenia decyzji administracyjnej może dojść także w postępowaniu sądowoadministracyjnym na podstawie art. $145 \S 1$ pkt 1 p.p.s.a. ${ }^{19} \mathrm{~W}$ tym przypadku podstawą uchylenia decyzji administracyjnej może być naruszenie prawa materialnego, które miało wpływ na wynik sprawy lub naruszenie prawa dające podstawę do wznowienia postępowania administracyjnego albo naruszenie przepisów postępowania, jeżeli mogło mieć istotny wpływ na wynik sprawy.

Zagadnienie związane z uchyleniem decyzji o zabezpieczeniu zasługuje na szczególną uwagę, gdyż decyzja ta stanowi podstawę wydania zarządzenia zabezpieczenia, na mocy którego dokonywany jest wpis hipoteki przymusowej. Należałoby zatem skupić się na relacji zachodzącej pomiędzy uchyleniem decyzji o zabezpieczeniu, wydanej na podstawie art. 33 § o.p., a zarządzeniem zabezpieczenia, o którym mowa w przepisach ustawy o postępowaniu egzekucyjnym w administracji.

Ustawodawca nie uregulował w sposób wyraźny określenia skutków uchylenia decyzji o zabezpieczeniu na wydane na jej podstawie zarządzenie zabezpieczenia, jak uczynił to w przypadku wygaśnięcia decyzji o zabezpieczeniu ${ }^{20}$, wskazując, że wygaśnięcie tej decyzji nie wpływa na ważność zarządzenia zabezpieczenia (art. 33a $\S 2$ o.p.). Wobec braku wyraźnej regulacji prawnej w kwestii skutków uchylenia decyzji o zabezpieczeniu, można by się odwołać per analogiam do regulacji zawartej w art. $154 \S 6$ u.p.e.a. Przepis ten stanowi, że zajęcie zabezpieczające nie przekształca się w zajęcie egzekucyjne w przypadku uchylenia przez organ odwoławczy lub sąd administracyjny decyzji stanowiącej podstawę dokonania zabezpieczenia, o ile wydanie nowej decyzji, nakładającej obowiązek podlegający wykonaniu w trybie przepisów o postępowaniu egzekucyjnym w administracji, nie nastapi w terminie 6 miesięcy od dnia doręczenia decyzji organu odwoławczego lub prawomocnego orzeczenia sądu administracyjnego organowi właściwemu do wydania decyzji. Zaznaczyć

18 Ustawa z 14 czerwca 1960 r. - Kodeks postępowania administracyjnego, t.jedn.: Dz. U. 2017, poz. 1257 (dalej jako: k.p.a.).

19 Ustawa z 30 sierpnia 2002 r. - Prawo o postępowaniu przed sądami administracyjnymi, t.jedn.: Dz. U. 2017, poz. 1369 (dalej jako: p.p.s.a.).

${ }^{20}$ Wyrok WSA w Poznaniu z 29 marca 2016 r., I SA/Po 2316/15, Legalis nr 1444205. 
przy tym należy, że postępowanie zabezpieczajace uregulowane w ordynacji podatkowej zawiera szczególne rozwiązania, które odbiegają od instytucji zabezpieczenia uregulowanej w ustawie o postępowaniu egzekucyjnym w administracji ${ }^{21}$.

W kwestii wpływu uchylenia decyzji o zabezpieczeniu na ważność zarządzenia zabezpieczenia kształtują się dwa przeciwstawne poglądy. Według pierwszego, uchylenie decyzji o zabezpieczeniu nie skutkuje obligatoryjnym uchyleniem zajęcia zabezpieczenia i zakończeniem postępowania zabezpieczającego prowadzonego na podstawie zarządzenia zabezpieczenia, o którym mowa w przepisach o postępowaniu egzekucyjnym w administracji ${ }^{22}$. Sądy administracyjne, powołując się na treść art. $154 \S 6$ u.p.e.a., wskazuja, że uchylenie przez organ odwoławczy lub sąd administracyjny decyzji określajacej przybliżoną kwotę zobowiązania podatkowego (decyzja o zabezpieczeniu) nie narusza zajęcia zabezpieczenia. Warunkiem utrzymania zabezpieczenia jest wydanie przez organ podatkowy (w terminie 6 miesięcy od dnia doręczenia mu decyzji organu odwoławczego lub prawomocnego orzeczenia sądu administracyjnego) nowej decyzji nakładajaccej obowiązek podlegajaccy wykonaniu w trybie przepisów o postępowaniu egzekucyjnym w administracji. Prezentowany pogląd szeroko ujmuje zakres stosowania regulacji art. $154 \S 6$ u.p.e.a.

Według drugiego poglądu, regulacja art. $154 \S 6$ u.p.e.a. znajduje zastosowanie w sprawach, w których podstawą dokonania zabezpieczenia była decyzja nakładająca obowiązek podlegający wykonaniu w trybie przepisów o postępowaniu egzekucyjnym $\mathrm{w}$ administracji ${ }^{23}$. W decyzji o zabezpieczeniu nie orzeka się o tego rodzaju obowiązku, a więc można wnioskować, że przepis ten nie będzie miał zastosowania ${ }^{24}$. Oznacza to, że przepis art. $154 \S 6$ u.p.e.a. będzie miał zastosowanie wyłącznie w sprawach, w których przedmiotem oceny zgodności z prawem, dokonywanej przez organ odwoławczy lub sąd administracyjny, będzie decyzja, w której orzeczono o obowiązku podlegającym egzekucji administracyjnej ${ }^{25}$. Brak możliwości zastosowania regulacji art. 154 $\S 6$ u.p.e.a (wystawienia nowej decyzji) stwarza podstawy do uchylenia przez organ egzekucyjny zarządzenia zabezpieczenia lub przynajmniej zmiany sposobu lub zakres zabezpieczenia w trybie art. 157a u.p.e.a. Podkreślić jednak należy, że przepis ten normuje fakultatywną przesłankę uchylenia lub zmiany sposobu zabezpieczenia, a jedynym kryterium jest decyzja uznaniowa organu.

Prezentowane stanowiska prowadzą do odmiennych wniosków, pierwsze daje podstawę do utrzymania w mocy zarządzenia zabezpieczenia stanowiącego podstawę wpisu hipoteki przymusowej. Drugie wskazuje na możliwość uchylenia zarządzenia zabezpieczenia, co w konsekwencji może być podstawa

${ }_{21}$ P. Przybysz, Postepowanie egzekucyjne $w$ administracji. Komentarz art. 154, Lex 2015, nb. 1.

${ }^{22}$ Wyrok WSA w Poznaniu z 29 marca 2016 r., I SA/Po 2316/15, Legalis nr 1444205 oraz wyrok NSA z 27 września 2012 r., I FSK 1578/11, Legalis nr 779785.

${ }^{23}$ D.R. Kijowski (red.), Ustawa o postepowaniu egzekucyjnym $w$ administracji, Warszawa 2015, s. 1249 .

24 Ibidem.

25 Ibidem. 
do złożenia apelacji w postępowaniu wieczystoksięgowym, z uwagi na pojawienie się nowych dowodów nieznanych sądowi pierwszej instancji. W celu wyjaśnienia rozbieżności pomiędzy stanowiskami prezentowanymi w doktrynie i orzecznictwie należałoby odwołać się do wykładni literalnej przepisu art. 154 § 4-6 u.p.e.a. Regulacja art. 154 § 4-5 u.p.e.a. odnosi się do instytucji przekształcenia, z mocy prawa, zajęcia zabezpieczającego w zajęcie egzekucyjne z chwila wygaśnięcia decyzji o zabezpieczeniu ${ }^{26}$. Warunkiem przekształcenia jest wystawienie tytułu wykonawczego nie później niż przed upływem 14 dni od dnia jej wygaśnięcia bądź z dniem wystawienia tytułu wykonawczego, o ile nastapiło nie później niż przed upływem 2 miesięcy od dnia doręczenia ostatecznej decyzji lub innego orzeczenia podlegajacego wykonaniu w spra$w^{27}{ }^{27}$. Natomiast w przypadku wniesienia skargi do sądu administracyjnego i wstrzymania wykonania decyzji zajęcie zabezpieczające przekształca się w zajęcie egzekucyjne $\mathrm{z}$ dniem wystawienia tytułu wykonawczego. Warunkiem przekształcenia jest wystawienie tytułu wykonawczego nie później niż przed upływem 2 miesięcy od dnia doręczenia odpisu prawomocnego orzeczenia o oddaleniu lub odrzuceniu skargi bądź umorzeniu postępowania sądowego. Przekształcenie to ma charakter warunkowy, konieczne jest więc wystapienie okoliczności wskazanych w art. $154 \S 4-6$ u.p.e.a. Regulacja przepisu art. 154 $\S 6$ u.p.e.a. dotyczy sytuacji, w których nie ma możliwości przekształcenia się zajęcia zabezpieczającego w zajęcie egzekucyjne w warunkach opisanych w art. $154 \S 4$ i 5 u.p.e.a., ponieważ decyzja w przedmiocie zabezpieczenia została uchylona. Pomimo uchylenia decyzji w przedmiocie zabezpieczenia przez organ odwoławczy lub sąd zabezpieczenie pozostaje w mocy, jeżeli w ciagu 6 miesięcy od dnia doręczenia decyzji organu odwoławczego lub prawomocnego orzeczenia sądu administracyjnego właściwy organ wyda nową decyzję nakładająca obowiązek podlegający wykonaniu w trybie przepisów o postępowaniu egzekucyjnym w administracji. Podkreślić należy, że w przepisie tym mowa jest o dwóch decyzjach, tj. decyzji stanowiącej podstawę do dokonania zabezpieczenia oraz decyzji nakładającej obowiązek podlegający wykonaniu $\mathrm{w}$ trybie egzekucji ${ }^{28}$.

Decyzją nakładająca obowiązek podlegający wykonaniu w trybie egzekucji jest np. decyzja ustalająca wysokość zobowiązania podatkowego czy też decyzja określająca wysokość zobowiązania podatkowego, o których mowa w art. $33 \S 2$ o.p. (decyzja zobowiązaniowa). Zgodzić się należy ze stanowiskiem prezentowym w doktrynie ${ }^{29}$, co do kwestii, że w decyzji o zabezpieczeniu nie orzeka się o obowiązku podlegajacym wykonaniu w trybie egzekucji. Decyzja o zabezpieczeniu jest decyzją stanowiąca podstawę do wystawienia zarządzenia zabezpieczenia. Jest to szczególny rodzaj decyzji, w której określana jest przybliżona kwota zobowiązania podatkowego, na podstawie której możliwe jest dokonanie zabezpieczenia przed terminem płatności. W świetle

${ }^{26}$ R. Hauser, Komentarz do art. 154, w: idem (red.), A. Skoczylas, Postępowanie egzekucyjne $w$ administracji. Komentarz, Legalis 2018, nb. 6.

${ }^{27}$ Ibidem.

${ }^{28}$ Wyrok NSA z 9 maja 2017 r., II FSK 276/17, Legalis nr 1651949.

${ }^{29}$ Zob. D.R. Kijowski (red.), op. cit., s. 1249. 
poczynionych uwag można przychylić się do tezy wyrażonej w orzecznictwie, że zarządzenie zabezpieczenia, o którym mowa w przepisach u.p.e.a., pozostaje w mocy pomimo uchylenia decyzji o zabezpieczeniu. Konieczne jest jednak wydanie przez właściwy organ, w terminie 6 miesięcy od dnia dręczenia decyzji organu odwoławczego lub prawomocnego orzeczenia sądu administracyjnego, nowej decyzji nakładajacej obowiązek podlegajacy wykonaniu w trybie przepisów u.p.e.a. Podkreślić jednak należy, że przepis ten dotyczy instytucji przekształcenia zajęcia zabezpieczającego w zabezpieczenie egzekucyjne, do którego dochodzi z mocy prawa z chwilą wygaśnięcia decyzji o zabezpieczeniu.

Jeżeli jednak w wyniku kontroli administracyjnej lub sądowoadministracyjnej decyzja stanowiaca podstawę do dokonania zabezpieczenia została uchylona, organ administracji publicznej, w celu utrzymania zajęcia zabezpieczenia (a właściwie przekształcenia go w zajęcie egzekucyjne), powinien wydać nową decyzję nakładająca obowiązek podlegający wykonaniu w trybie przepisów o postępowaniu egzekucyjnym w administracji. Termin na wydanie nowej decyzji wynosi 6 miesięcy od dnia doręczenia decyzji organu odwoławczego lub prawomocnego orzeczenia sądu administracyjnego organowi właściwemu do wydania decyzji. Regulacja ta może budzić pewne wątpliwości.

Po pierwsze, stwierdzenie „decyzja stanowiąca podstawę do dokonania zabezpieczenia" może także sugerować decyzję, o której mowa w art. 110 pkt 3 u.k.w.h. (decyzja administracyjna, o ile przepisy szczególne tak stanowia, chociażby decyzja nie była nieostateczna). Przykładem takiej decyzji może być decyzja, o której mowa w art. 26 ust. 3 u.s.u.s. ${ }^{30}$ (decyzja określajaca wysokości należności z tytułu składek), czy też decyzja ustalająca wysokość zobowiązania podatkowego, określająca wysokość zobowiązania podatkowego, o której mowa w art. 33 § 2 pkt 1 i 2 o.p. Decyzje te moga stanowić samodzielna podstawę wpisu hipoteki przymusowej, bez konieczności wydawania zarządzenia zabezpieczenia, jak również nakładać obowiązek podlegający wykonaniu w trybie przepisów o postępowaniu egzekucyjnym w administracji.

Po drugie, przepis art. $154 \S 6$ u.p.e.a. wskazuje na możliwość przekształcenia się zajęcia zabezpieczającego w zajęcie egzekucyjne w przypadku uchylenia przez organ odwoławczy lub sąd administracyjny decyzji stanowiacej podstawę do dokonania zabezpieczenia (wpisu hipoteki przymusowej), jeżeli $\mathrm{w}$ przepisanym terminie właściwy organ wyda nową decyzję. Jest to przepis stricte odnoszacy się do egzekucji administracyjnej i, jak się wydaje, trudno go bezpośrednio odnosić do uchylenia decyzji o zabezpieczeniu, która - co należy podkreślić - nie jest decyzją stanowiąca podstawę dokonania zabezpieczenia, a jedynie daje podstawę do wystawienia administracyjnego zarządzenia zabezpieczenia. Zastosowanie per analogiam regulacji art. $154 \S 6$ u.p.e.a. do relacji zachodzacej pomiędzy uchyleniem decyzji o zabezpieczeniu a utrzymaniem skutków prawnych zarządzenia zabezpieczenia jako merytorycznej podstawy wpisu hipoteki przymusowej daje podstawę do utrzymania w mocy zarządzenia zabezpieczenia, gdyż została wydana nowa decyzja nakłada-

30 Ustawa o systemie ubezpieczeń społecznych z 13 października 1998 r., t.jedn.: Dz. U. 2017, poz. 1778 (dalej jako: u.s.u.s.). 
jąca obowiązek podlegający wykonaniu w trybie przepisów o postępowaniu egzekucyjnym w administracji. Prowadzi to $\mathrm{w}$ konsekwencji do utrzymania w mocy zarządzenia zabezpieczenia jako merytorycznej podstawy wpisu hipoteki przymusowej. Pogląd o zastosowania regulacji wzorowany na art. 154 $\S 6$ u.p.e.a. jest do zaakceptowania, jednakże wydaje się, że de lege ferenda można by wprowadzić odpowiednią regulację prawną lub przynajmniej zastosować odesłanie do odpowiedniego stosowania przepisów już istniejących. Rozwiałoby to wątpliwości pojawiające się w doktrynie i orzecznictwie.

IV. Sąd wieczystoksięgowy związany jest dokumentami urzędowymi sporządzonymi w przepisanej formie przez ograny władzy publicznej na podstawie art. 244 k.p.c. Oznacza to, że sąd wieczystoksięgowy nie jest uprawniony do kontroli merytorycznej decyzji administracyjnej ${ }^{31}$ ani aktu administracyjnego, jakim jest zarządzenie zabezpieczenia. Kontrola aktów administracyjnych przeprowadzana jest przez organy administracyjne i są administracyjne w odrębnych postępowaniach. Sąd wieczystoksięgowy może kontrolować akty administracyjne jedynie w zakresie, czy nie zostały one wydane przez niewłaściwy organ lub bez jakiejkolwiek podstawy prawnej względnie z oczywistym naruszeniem prawa administracyjnego ${ }^{32}$.

Należałoby zatem rozważyć, czy upadek skutków zarządzenia zabezpieczenia stanowiącego podstawę wpisu hipoteki przymusowej ma wpływ na postępowanie wieczystoksięgowe. Sytuacja taka zachodzi w przypadku uchylenia decyzji o zabezpieczeniu, kiedy nie ma podstaw do utrzymania bytu prawnego zarządzenia zabezpieczenia, jako merytorycznej podstawy zabezpieczenia. W tym zakresie przeanalizować należy dwie sytuacje: pierwsza, kiedy do uchylenia zarządzenia zabezpieczenia dochodzi po złożeniu wniosku o wpis hipoteki przymusowej. Druga, gdy okoliczność ta wyjdzie na jaw dopiero w postępowaniu apelacyjnym.

Kognicję sądu w postępowaniu wieczystoksięgowym określa art. $626^{8}$ $\S 2$ k.p.c., zgodnie z którym sąd, rozpoznając wniosek o wpis, bada jedynie treść i formę wniosku, dołączonych do wniosku dokumentów oraz treść księgi wieczystej. Szczególną uwagę należy zwrócić na zawarte w omawianym przepisie sformułowanie „bada jedynie”, które wskazuje na ograniczony charakter kognicji sądu w postępowaniu wieczystoksięgowym. Sąd nie ma uprawnień ani możliwości prowadzenia postępowania dowodowego, nie może także weryfikować danych podawanych przez strony ${ }^{33}$. Przepis ten określa kognicję sądu wieczystoksięgowego zarówno pierwszej, jak i drugiej instancji. Oznacza to, że regulacja zawarta w art. $626^{8} \S 2$ k.p.c. zawiera nummerus clausus źródeł dowodowych ${ }^{34}$. Postępowanie wieczystoksięgowe jest postępowaniem nieprocesowym, wynika to explicite z regulacji art. 507 k.p.c. Sąd, rozpoznając

\footnotetext{
${ }^{31}$ K. Knoppek, Dokumenty w procesie cywilnym, Poznań 1993, s. 103-106.

${ }^{32}$ Uchwała SN z 9 października 2007 r., III CZP 46/07, „Orzecznictwo Sądu Najwyższego” 2008, nr 3, poz. 30.

${ }^{33}$ Postanowienie SN z 5 stycznia 2011 r., III CSK 84/10, Legalis nr 370381.

${ }^{34}$ Wyrok SN z 19 marca 2003 r., I CKN 152/01 z glosa: T. Czech, „Monitor Prawniczy” 2005, nr 21, s. 1081, z glosą: R. Rudnicki, „Orzecznictwo Sądów Polskich” 2004, nr 2, poz. 20, s. 81.
} 
wniosek o wpis w księdze wieczystej, związany jest stanem rzeczy istniejacym w chwili złożenia wniosku i kolejnością jego wpływu ${ }^{35}$. Brak także podstaw do stosowania w postępowaniu wieczystoksięgowym regulacji art. 316 k.p.c. w zw. z art. $13 \S 2$ k.p.c., odnoszącego się do odpowiedniego stosowania przepisów o procesie, biorąc za podstawę stan rzeczy istniejący w chwili zamknięcia rozprawy ${ }^{36}$. Oznacza to, że czynności podejmowane (np. uchylenie zarządzenia zabezpieczenia na podstawie art. $157 \mathrm{a}$ u.p.e.a.) po złożeniu wniosku o wpis hipoteki przymusowej nie mogą zostać uwzględnione w postępowaniu wieczystoksięgowym w pierwszej instancji, ponieważ sąd związany jest stanem rzeczy z chwili złożenia wniosku. Okoliczność uchylenia zarządzenia zabezpieczenia może być jednak podstawą założenia apelacji, gdyż stanowi nowy dowód nieznany sądowi pierwszej instancji.

Powołanie się na nowe fakty lub dowody przez uczestnika postępowania w postępowaniu apelacyjnym nie może zostać uwzględnione, jeżeli miałyby one stanowić podstawę uwzględnienia wniosku ${ }^{37}$. Jeżeli jednak nowe okoliczności wskazują na istnienie przeszkody uwzględniania wniosku, apelacja może zawierać powołanie nowych faktów i dowodów. Konieczne jest wówczas wykazanie, że powołanie nowych dowodów nie było możliwe w postępowaniu przed sądem pierwszej instancji albo że potrzeba powołania się na nie wynikła później ${ }^{38}$ (regulacja art. $368 \S 1$ pkt 4 k.p.c. w zw. z art. $13 \S 2$ k.p.c.). Ocena okoliczności stanowiących przeszkodę dokonania wpisu hipoteki przymusowej musi nastapić według stanu z chwili jego dokonania.

V. Hipoteka przymusowa jest szczególną odmianą zabezpieczenia zobowiązań podatkowych, której celem nie jest doprowadzenie do ich przymusowego dochodzenia, a jedynie zagwarantowanie środków na ich zaspokojenie w przyszłości. Zobowiązania podatkowe zabezpieczone hipoteka nie ulegaja bowiem przedawnieniu, jednakże po upływie terminu przedawnienia zobowiązania te mogą być egzekwowane tylko z przedmiotu hipoteki (art. 70 § o.p.).

Organy podatkowe moga wnioskować o zabezpieczenie hipoteka przymusową należności podatkowych, nawet przed wydaniem decyzji, o której mowa w art. $35 \S 2$ o.p. Wówczas na podstawie posiadanych danych co do wysokości podstawy opodatkowania wydawana jest decyzja określająca przybliżona kwotę zobowiązania podatkowego (decyzja o zabezpieczeniu). Decyzja ta stanowi podstawę wystawienia zarządzenia zabezpieczenia, o którym mowa w przepisach ustawy o postępowaniu egzekucyjnym w administracji. Zarządzenie zabezpieczenia stanowi jedną z podstaw wpisu hipoteki przymusowej, o której mowa w art. 110 u.k.w.h.

${ }^{35}$ Uchwała składu siedmiu sędziów - zasada prawna - SN z 16 grudnia 2009 r., III CZP 80/09, „Orzecznictwo Sądu Najwyższego Izba Cywilna” 2010, nr 6, poz. 84.

${ }^{36}$ Uchwały SN: składu siedmiu sędziów - zasada prawna - z 16 grudnia 2009 r., III CZP 80/09, „Orzecznictwo Sądu Najwyższego Izba Cywilna” 2010, nr 6, poz. 84; z 25 lutego 2016 r., III CZP 86/15, Legalis nr 1406283.

37 Postanowienie SN z 24 września 2015 r., V CSK 690/14, Legalis nr 1372875.

38 Postanowienie SN z 12 stycznia 2012 r., IV CSK 251/11, Legalis nr 480493. 
Pojawiają się wątpliwości, co się dzieje z zarządzeniem zabezpieczenia w przypadku uchylenia decyzji o zabezpieczeniu. Czy można przyjać, że uchylenie decyzji o zabezpieczeniu powoduje odpadnięcie podstawy prawnej wystawienia zarządzenia zabezpieczenia. W orzecznictwie wskazuje się, że zajęcie zabezpieczenia pozostaje w mocy, jeżeli właściwy organ wyda nową decyzję nakładającą obowiązek podlegający wykonaniu w trybie przepisów u.p.e.a. ${ }^{39}$ Decyzja taka powinna być wydana w terminie 6 miesięcy od dnia doręczenia decyzji organu odwoławczego lub prawomocnego orzeczenia sądu administracyjnego organowi właściwemu do wydania decyzji (art. $154 \S 6$ u.p.e.a). Można się zgodzić z zaprezentowanym stanowiskiem, zaznaczyć jednak należy, że przepis art. $154 \S 6$ u.p.e.a. znajduje zastosowanie na gruncie egzekucji administracyjnej i, jak się wydaje, trudno go bezpośrednio odnosić do relacji zachodzacej pomiędzy uchyleniem decyzji o zabezpieczeniu a wydanym na jej podstawie zarządzeniem zabezpieczenia. De lege ferenda można by wprowadzić odpowiednią regulację prawną lub przynajmniej zastosować odesłanie do odpowiedniego stosowania przepisów już istniejących. Rozwiałoby to wątpliwości pojawiające się w doktrynie i orzecznictwie.

Jeżeli dojdzie do uchylenia aktu administracyjnego stanowiącego podstawę wpisu hipoteki przymusowej, okoliczność ta może stanowić nowy dowód w wieczystoksięgowym postępowaniu apelacyjnym, ponieważ wskazuje na istnienie przeszkody dokonania wpisu hipoteki przymusowej. Sąd może oprzeć się na dokumentach przedstawionych $\mathrm{w}$ apelacji, jednakże ich ocena powinna nastapić według stanu rzeczy z chwili złożenia wniosku.

mgr Agnieszka Polus

Uniwersytet Mikotaja Kopernika w Toruniu

a.polus@doktorant.umk.pl

\author{
AN ADMINISTRATIVE ORDER TO SECURE A CLAIM \\ AS A BASIS FOR AN ENTRY OF A COMPULSORY MORTGAGE
}

Summary

The main subject of the discussion concerns issues related to securing tax obligations before issuing a decision setting or determining the amount of tax liability. In such a case, the tax authority issues a decision determining the approximate amount of the tax liability (decision on securing), under which the order for the collateral is issued. First, issues related to the expiration and revocation of a decision on securing are discussed. Then, the impact of the revoked decision on the validity of the collateral order is presented, and the effects of the revocation of an administrative act in administrative proceedings on the land and mortgage register proceedings are discussed. The author also attempts to answer the question whether revocation of an administrative act constituting the basis for an entry of a compulsory mortgage may constitute a new fact or evidence in the appellate proceedings concerning the land and mortgage register.

${ }^{39}$ Zob. np. wyrok WSA w Poznaniu z 29 marca 2016 r., I SA/Po 2316/15, Lex nr 2022137. 
